\title{
The Development of Terrestrial Laser Scanning Technology And Its Applications in Mine Shafts in Poland
}

\author{
Tomasz LIPECKI ${ }^{1, *}$, Kim THI THU HUONG ${ }^{1,2)}$
}

\begin{abstract}
${ }^{1)}$ Department of Mining Area Protection, Geoinformatics and Mining Surveying, Faculty of Mining Surveying and Environmental Engineering, AGH University of Science and Technology, al. Mickiewicza 30, 30-059 Krakow, Poland; email: lipecki@agh.edu.pl

2) Department of Geodesy, Hanoi University of Mining and Geology, Vietnam; email: kimthithuhuong@humg.edu.vn
\end{abstract}

\section{http://doi.org/10.29227/IM-2020-02-36}

Submission date: 06-03-2020 | Review date: 22-09-2020

Abstract
Laser scanners are used more and more as surveying instruments for various applications. With the advance of high precisions
systems, laser scanner devices can work in most real-world environments under many different conditions. In the field of mining
surveying open up a new method with data capturing. Mining industry requires precise data in order to be able to have a as-built
documentation of the facility. Nowadays, the mines are increasingly deepened. For the safe operation of the underground mine, special
attention is paid to vertical transport and a set of devices supporting it, mounted in mining shafts. All components must meet stringent
criteria for proper operation. The classic geodetic measurements and mechanical tests are long-lasting and do not always provide the
full range of information needed about the condition of the object. This paper reports about terrestrial laser scanning method and
system mobile terrestrial laser scanning, which has been applied at many vertical shafts in mines of Poland for determining geometric
deformation of vertical shaft elements. This system gives high precision 1-3 mm in every horizontal cross-section. Processing time is
very quickly and need only few staff to implement all system.

Keywords: Terrestrial Laser Scanning, Mobile Terrestrial Laser Scanning, Polish Mining Surveying System

\section{Introduction}

Terrestrial laser scanner (TLS) is an innovation in spatial information data acquisition, which allows data capturing with unprecedented resolution and accuracy. With a wide application, TLS has many advantages compared to traditional geodetic methods. Data scanned from TLS are of 3D point clouds with millions of points, which can subsequently be converted to $2 \mathrm{D}$ data used in various computer programs, such as AutoCAD, MicroStation, MicroMine. Point clouds clearly show geospatial data for the mine at the millimeters precision. TLS has very high-rate scan at $10000-1000000$ points per second with very quick measurement. Additionally, it can work in difficult conditions, which do not need to contact directly with dangerous areas (e.g., locations have risk of rock subsidence), so the safety of fieldwork is improved (Nghĩa \& Dũng, 2016). TLS is suitable for small and medium areas. In theory, scan distance can reach to $6000 \mathrm{~m}$. Scanned points' precision can be up to $2 \mathrm{~mm}$ (example for Trimble TX5 Laser Scanning with scan distances less than $120 \mathrm{~m}$ ). TLS technology is used in mining geodesy, specifically in checking surface and axes of vertical shafts, updating measure changes in mines (such as movement, mining shocks, broken locations, mineral structures, and mass calculation). In cases of accident in mine, managers and rescuers could easier have information, coordinates of places (which accident was happened) very clearly, quickly on the 3D model. From there, people can make a relief plan accurately and quickly.

TLS technology nowadays has been used widely in the European countries in many fields: 3D mapping (Gallay et al., 2015), civil engineering (Abmayr, Härtl, Reinköster, \& Fröhlich, 2005; Berenyi, Lovas, \& Barsi, 2010), architecture (Moor- thy et al., 2011), archaeology (Lerma, Navarro, Cabrelles, \& Villaverde, 2010), cultural heritage protection (Abmayr et al., 2005), and also mining and mineral industry (Adamek A., 2014; Lipecki, Ligarska, \& Zawadzka, 2018). For the mining industry, the open-pit mine's reserve coal decrease day by day, many coal mines have expanded production to exploit deeper underground with vertical shafts. In Poland, the first vertical shaft was built about 650 years ago in Salt Mine Bochnia near Kraków City. The deepest shaft reaches over $1200 \mathrm{~m}$ below the terrain surface. The previous time, mine's geometrical features, such as shafts, a path in the mine etc. - were often measured by meters or electronic total station devices with a small number of points and low precision. For the last two decades, laser scanners, in which the Cartesian coordinates of millions of points belonging to any reflecting surface are obtained only in a few minutes, have been used incrementally for the geometric modeling of shaft mine structures.

TLS and mobile TLS have been used in Poland for the vertical shafts since early of XXI century. Due to the shape of the shaft, as well as the functions performed, making all geodetic measurements is very difficult. The mobile laser scanning process can reduce time duration and operational budget by a significant margin and produce $100 \%$ accurate results without any hassle. The use of laser scanning requires application appropriate measurement procedures enabling the reconstruction of the examined space in the form of a metric digital model. It is most suitably way for measurement contents, shaft geospatial data collection, serving the process of exploring, building, exploiting, renovating and restoring the environment after mineral exploitation. Laser scanning allows you to obtain such a large range of information that is 


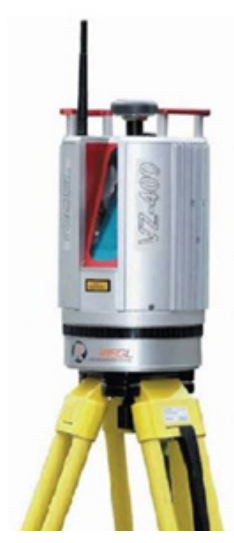

Fig. 1. Pulse based laser scanner (Source: Riegl) Rys. 1. Impulsowy laserowy skaner
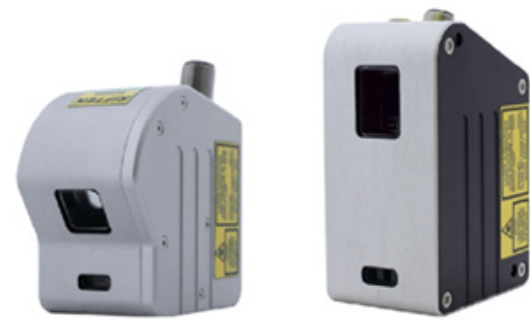

Fig. 2. Phase based laser scanner: FARO FOCUS LASER SCANNER (the perfect instruments for 3D reality capture for AEC, Public Safety-Forensics and Product Design Applications)

Rys. 2. Fazowy skaner laserowy: FARO FOCUS LASER SCANNER (doskonałe przyrządy do zrobienia rzeczywistości 3D dla AEC, kryminalistyki bezpieczeństwa publicznego i aplikacji do projektowania produktów)

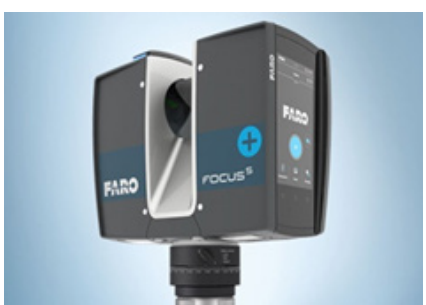

Fig. 3. Triangulation laser scanner RF627 series, Riftek

Rys. 3. Laserowy skaner triangulacyjny serii RF627, Riftek

not possible to obtain by classical research methods. However, it requires a combination of point clouds and references to external systems.

In this paper, it will be reported about terrestrial laser scanning and system mobile terrestrial laser scanning. This mobile TLS system is studied and created by company SKALA 3D Poland under the POIG project, action in 1.4 of PARP. This is the specialist mobile automated system conducting spatial measurements of mining shaft geometry using laser scanning technology. It is also named the Mobile Mining System (MMS). The system is based on data from scanners laser and precision inertial unit. The main research problem was determining the trajectory of the Mobile Mining Platform with the largest possible accuracy. In progress, the projects have numerous research problems, including the need to define physical references, IMU drift or harsh weather conditions. The SKALA 3D company has solved these problems, makes the MMS unique in the world. (Adamek, 2015).

\section{Overview of terrestrial laser scanning \\ 2.1 Classification}

Terrestrial laser scanning referred to as terrestrial LIDAR (Light detection and ranging) or topographic LiDAR, acquires XYZ coordinates of numerous points on land by emitting laser pulses toward these points and measuring the distance from the device to the target (Vosselman \& Maas, 2010). Base on the measurement principle, the terrestrial laser scanning has been segmented as follows:

- pulse-based scanner (Time of flight)

- $\quad$ phase-based scanner (phase measurement)

- Optical triangulation (Sheet-of-light)

Time-of-flight technique allows measurements in distances up to several hundred meters. The accuracy of TOF is determined by the system's ability to accurately measure the time of the returning signal. Although exact specifications vary between different systems, the typical accuracy for TOF system is $4-10 \mathrm{~mm}$. There are many companies which produce 
Tab. 1. Classification of terrestrial laser scanners

Tab.1. Klasyfikacja naziemnego skanera laserowego

\begin{tabular}{|l|l|l|l|}
\hline Measurement technology & Range (m) & Accuracy $\mathbf{( m m})$ & Manufacturers \\
\hline Time of flight & $<100$ & $<10$ & $\begin{array}{l}\text { Callidus, Mensi, Optech, Leica, } \\
\text { Riegl, Trimble }\end{array}$ \\
\hline & $<1000$ & $<20$ & Optech, Riegl \\
\hline Phase measurement & $<100$ & $<10$ & $\begin{array}{l}\text { Faro, Leica, Zoller+ } \\
\text { Fröhlich, IQSun, VisImage }\end{array}$ \\
\hline Optical triangulation & $<5$ & $<1$ & Mensi, Minolta, Riftek \\
\hline
\end{tabular}

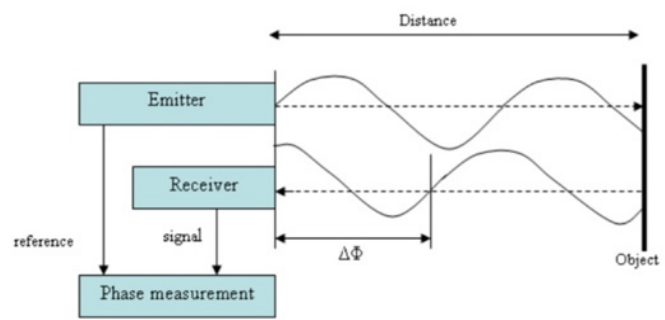

Fig. 4. Phase- base measurement principle (Quintero et al., 2008)

Rys. 4. Zasada pomiaru fazowego

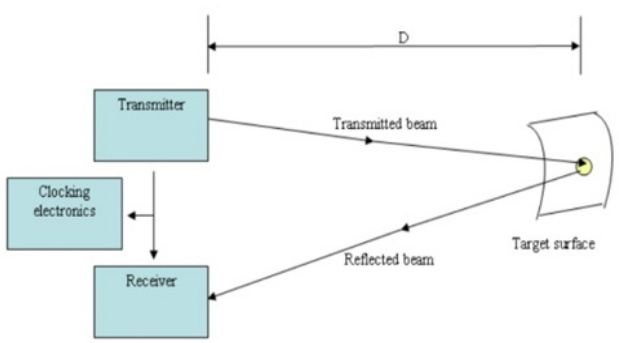

Fig. 5. Pulse based laser scanner principle

Rys. 5. Zasada laserowego skanera impulsowego

pulse-based laser scanners. Some of them are Callidus, Mensi, Optech, Leica, Riegl, Trimble (Fig. 1).

Beside pulse-based laser scanners with the TOF principle, the phase measurement principle represents the other technique for medium ranges. This technique allows measurement up to hundreds of meters. Phase-based scanners today collect vast amounts of data, up to 500,000 points per second, but they are limited in range $(<100$ feet) for high precision works. Phase-based laser scanners have been produced by companies, such as Faro, Leica, Zoller+Fröhlich, IQSun, VisImage (Fig.2).

Optical triangulation principle is in the short-range scanners (Fig. 3). It is used to scan individual objects (e.g. tools, antiquity etc.) These scanners operate on the principle of triangulation where a laser is emitted and returned to a specific location on a CCD array of an inboard camera. Most triangular systems come with a set of lenses that change the field of view of the system. White light or edge projection systems also use the principle of triangulation. Triangular systems typically have an operating range of 0.5-5 meters and accuracies down to some micro-meters.

\subsection{Principle of a terrestrial laser scanner}

Phase-based scanner and Pulse-based scanner are both time-based laser scanners. Means they measure the difference time between transmission and reception.

\section{Phase based scanners}

The time measured by a phase scanner is realized by emitting a continuously modulated laser beam and by measuring the phase difference between the transmitted and the received pulse. (Fig.4).

The emitted light is modulated in amplitude and fired onto a surface. The scattered reflection is collected, and a circuit measures the phase difference between the sent and received waveforms, therefore a time delay. The relationship between phase difference, modulation frequency ( ) and time delay $(\mathrm{t})$ is:

$t=\frac{\Delta \emptyset}{2 \pi \cdot f_{\bmod \text { ulated }}}$

Then, the measuring distance of the time-of-flight scanner

$d=\frac{c t}{2}=\frac{c}{4 \pi} * \frac{\Delta \emptyset}{f_{\text {mod ulated }}}$

$\mathrm{c}$ - the speed of light in air, $\mathrm{t}$ - the time between sending and receiving the signal.

\section{Pulse laser beam scanners}

Pulse laser beam scanners transmit a short laser pulse. They also record the time between transmitted and received pulse (Fig.5). A pulse-based laser scanner operates using just 'time-of-flight'. A pulse of light is sent, and the time it takes to reflect back is measured. This is only suitable for very long 


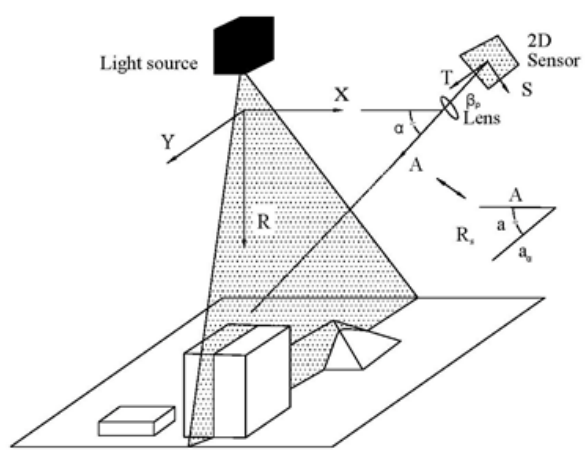

Fig. 6. Laser triangulation principle

Rys. 6. Zasada triangulacji laserowej

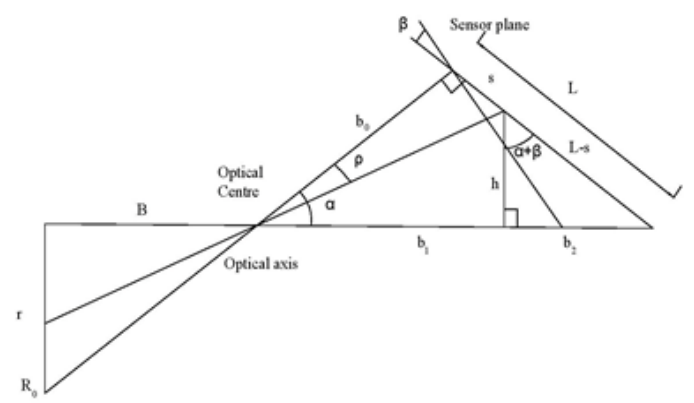

Fig. 7. Geometric relations in triangulation

Rys. 7. Relacje geometryczne w triangulacji

distances (to $\mathrm{km}$ ) where the time of flight is long enough to be measured by electronic methods.

The distance to the surface can be count by using formula: $\mathrm{d}=\mathrm{ct} / 2$ (3) (Quintero et al., 2008).

Advanced phase base scanners give more clean data than pulse-based scanners up to and beyond 50m. Phase based scanners measure far quicker over a short-range and can acquire far denser datasets. (Romsek, 2008).

\section{Optical triangulation laser scanners}

Optical triangulation laser scanners are operated based on the method called triangulation or sheet-of-light range imaging.

The object is illuminated from one direction with a laser line projector and viewed by the camera from another direction, as shown in Fig. 6 . The illumination angle, the viewing angle and the baseline between the illuminator and the camera determine the triangulation geometry from which the camera calculates the $3 \mathrm{D}$ shape. The exact height of each point on the laser line can be calculated by intersecting the corresponding camera projection ray with the optical triangulation scanner. The geometrical relationship for parameters of a laser scanner, camera and their relative positions is shown in Fig. 7. (Kumar, Tiwari, \& Chaudhury, 2006)

Object height can be calculated by the following formula:

$$
\text { object height }=B \frac{\operatorname{ssec}^{2} \alpha}{b_{0}+\operatorname{stan} \alpha}
$$

\section{Terrestrial laser scanning technology and its applica-} tions in vertical shaft

\subsection{Vertical shafts and difficulties in measuring}

Mining vertical shafts are not only known basically as a form to exploit minerals, but they are also used for trans- portation, ventilation purposes: bringing in the clean wind, bringing out dirty wind, skips, carrying people and other technical work. They have a depth of several dozen to thousands of meters. Their shape is usually circular, but sometimes we may see an old form of a square or rectangular shape. It depends on geological conditions, building time and structures (concrete or reinforced concrete). Each component of each type of shafts has a defined size and shape. The shaft construction is also equipped with girders and guidelines (wooden or metal). The guidelines are hung as a kind of pull shaft (pull cartons and skips). Due to the presence of such components, the light in the shaft is reduced. The guidelines and the tops of skip also reduce visibility during scan laser. (Adamek, 2015)

\subsection{Applying TLS and MTLS technology in a vertical shaft in Poland}

In mining works, cause of above difficulties in using a terrestrial laser scanner, company Skala 3D created the special Polish Platform, which is named Mining Surveying System (MSS). MSS has been designed for surveying of mine shafts. However, it can also be used in everywhere, where GPS signal cannot reach, such as measurement in railway tunnels, measurement in subway tunnels. As far as we know, the essence of measurements in a shaft is the measurement of the geometry of shaft lining and reinforcement elements; measurement of the rectilinearity of the conveyance track and measurement of the play between the guides and the working surfaces of the slides in the shaft. (Adamek, 2015). In Fig. 8, this is a panorama of vertical shaft, which was measured by static TLS.

Fig. 9 is the point cloud from the vertical shaft, measured by mobile TLS using Polish platform. This system is based on the data streaming from laser scanners and inertial measure- 


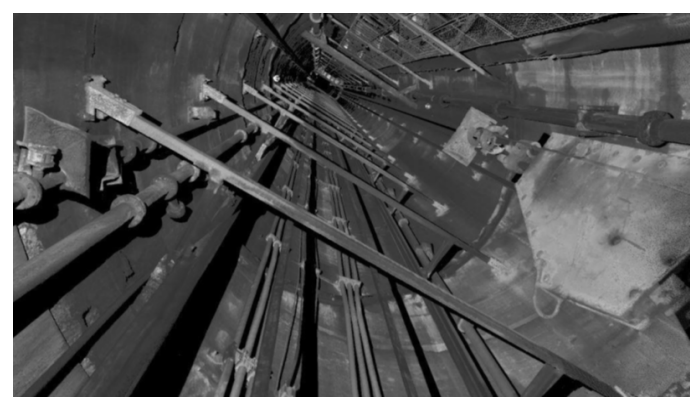

Fig. 8. Panoramic, static TLS

Rys. 8. Panoramiczny, statyczny TLS

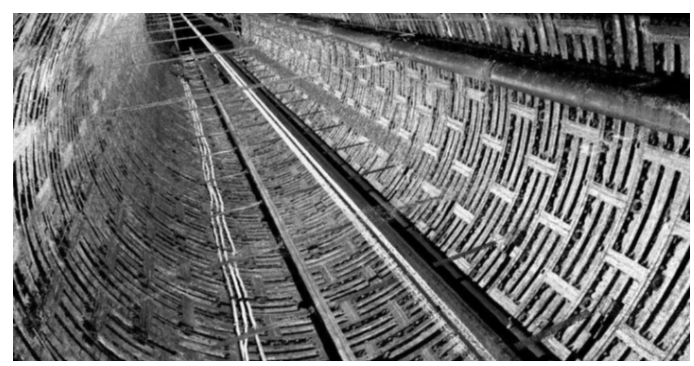

Fig. 9. Mobile TLS using the Polish platform (Adamek A., 2014) Rys. 9. Mobilny TLS na polskiej platformie

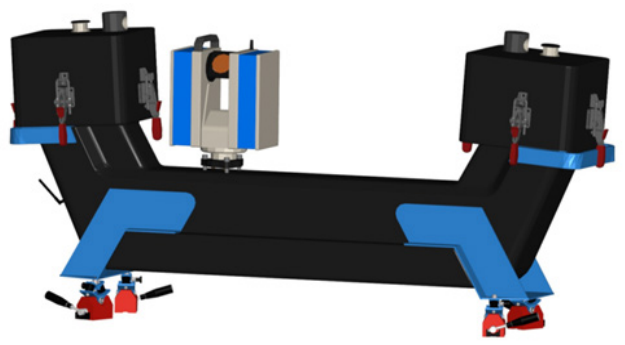

Fig. 10. Polish Mining Survey System (MSS) for geodetic mobile laser shaft inventory (Adamek A., 2014) Rys. 10. Polski Mobilna Platforma Górnicza (MPG) dla geodezyjnej mobilnej inwentaryzacji szybów laserowych

ment unit (IMU). The quality and accuracy of measurement in this system are increased with retrofitting a set of vibro-isolation parts preventing the transmission of vibrations while the cage is moving in the shaft and the system measurement. There are also control panel and processing data software. All of them make a calibration system, in which remote measurement has been done without stopping the operation of equipment in a short time. It is able to provide spatial measurement data from measured shaft - 2 days in the case of conventional methods and now only up to one shift if used mobile laser scanning. Moreover, the full-time ride of 1000 meters deep pipe shaft takes about 20 minutes. The accuracy in a single measurement is $1-3 \mathrm{~mm}$ in horizontal and $2-10 \mathrm{~cm}$ in the full length of vertical shafts (on the thousandth meter below ground) (Lipecki Tomasz Adamek A, 2016; Lipecki, 2013). That makes the system very accurate and unique in the world.

Fig. 10 is a Polish Mobile Mining Survey System (MSS) for geodetic laser inventory. "Heart of system" is a phased laser scanner 5010, which is produced by Zoller+Fröhlich company and Northrop Grumman LCI-100 inertial unit, on which supporting positioning mobile measuring system. Two PROFILER laser scanners 9012 of Zoller+Fröhlich, working only in one plane. They are dedicated specifically for dynamic measurement mobile. Z+F IMAGER 5010 panoramic scanner has a field of view 360 degrees. This allows to scan in the full horizon in the vertical axis and is standard for static measurements. It also complements the data acquired by PROFILE SCANNERS.

The other components of this system ensure:

1. automation - Automation of measuring and diagnostic operations

2. precision time source: precise synchronization system for measuring devices in real-time;

3. a set of vibration isolators preventing the transmission of some ascending vibrations while driving the conveyance track on the measuring system (Fig. 10);

4. non-invasiveness remote measurements without stopping the operation of equipment;

5. deformation monitoring - verification of the condition of objects changing in time;

6. short measurement time in the shaft - two days in the case of conventional methods and only up to one shift if mobile laser scanning is used

The MSS includes the following components:

1. Z+F IMAGER 5010 laser scanner; 


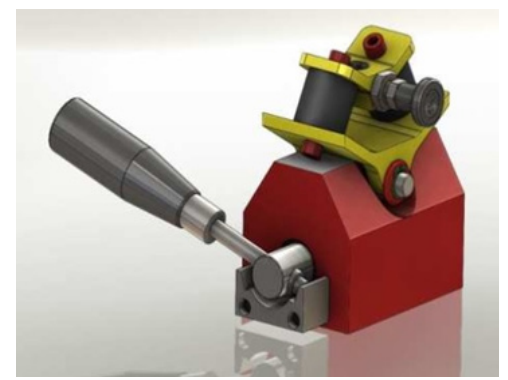

Fig. 11. Stabilization system and platform assembly (vibration isolators) (Adamek, 2015) Rys. 11. System stabilizacji i montaż platformy (wibroizolatory)

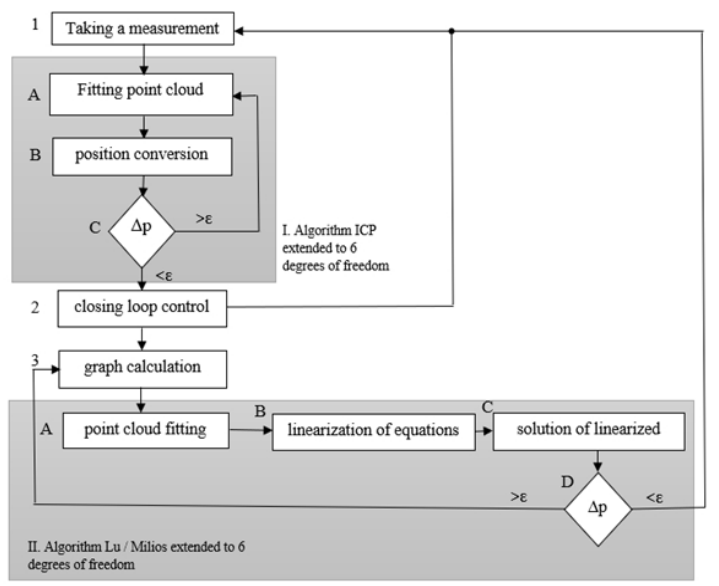

Fig. 12. Functional diagram of the SLAM 6D algorithm (Adamek, 2015) Rys. 12. Schemat funkcjonalny algorytmu SLAM 6D

2. 2 Z+F PROFILER 9012 laser scanners;

3. Inertial Measurement Unit (IMU) LCI-100;

4. Precision Time Source (PTS);

5. a set of electronic devices for controlling the platform;

6. platform power system;

7. MPG control and control software;

8. Dynamic Scan Calculation Software for special analyzing measurement.

\subsection{Using slam (simultaneous localization and mapping) method supports the position of mss in the shaft}

Measurements in mining shafts have some limitations, and one of them is the orientation and positioning of the measuring device under the Earth's surface. Therefore, the system's positioning determine was supported by a robotics solution. This solution automatically searches types of shapes and patterns during scanning. It uses the 6D SLAM algorithm, which developed by German scientists. In this algorithm, really three-dimensional images have been used to navigate the measuring platform. Operating of 6D SLAM necessary works with six free parameters: $\mathrm{x}, \mathrm{y}, \mathrm{z}, \omega, \lambda, \varphi$ - spatial coordinates and three angles of rotation around individual axes of the coordinate system. This is a characteristic feature of this algorithm. This is also a reason why it is named "6D". (Adamek, Bałchan, Krawiec, \& Lipecki, 2016)

The main task is the orientation of the next point clouds and adjusts the subsequent measurements so that the resulting model can be used to determine the position of the plat- form. In Fig. 12 shows a functional diagram of the SLAM 6D algorithm. (Tomasz Lipecki, 2015)

\subsection{Platform software}

TLS data, which is obtained by Polish Laser Scanner Platform, has been analyzed by a special software program (LiMine Software), which has been written by company SKALA 3D. This company has existed since 2003. SKALAD 3D is a Polish company, which has many experiences in photogrammetry and indoor mapping. They are particularly specialized in laser scanning and the development of mobile measurement systems.

It automatically analyzes and processes laser scanner data (Fig. 13 and Fig. 14) in each cross-section through the shaft, based on the measurement schema. Data is analyzed and exported in PDF Files and XLS Files. (Lipecki T. Adamek A, 2019).

Schema of postprocessing in LiMine Software is shown in the Figure 15.

- The effect of semi-automated software is set of products, where on the basis of the profiles (Fig. 13) we can obtain:

- Measurement of the rectilinearity of the conveyance track (Fig 16a);

- Measurement of the play between the guides and the working surfaces of the slides in the shaft;

- Measurement of the geometry of shaft lining and reinforcement elements;

- Deformation analysis - hypsometry (Fig. 16b) 


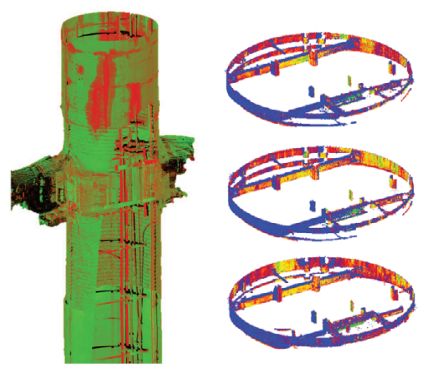

Fig. 13. Part of 3D model of the shaft geometry and horizontal cross-section Rys. 13. Część modelu 3D geometrii szybu i przekroju poziomego

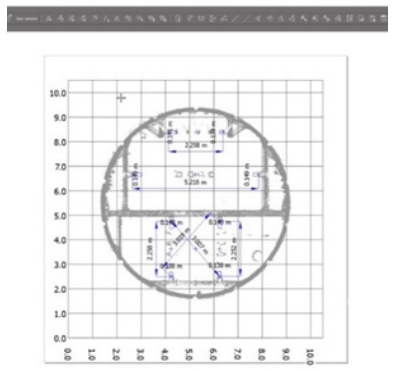

Fig. 14. Processing - schema document on the screen of software Rys. 14. Przetwarzanie - dokument schematu na ekranie programu

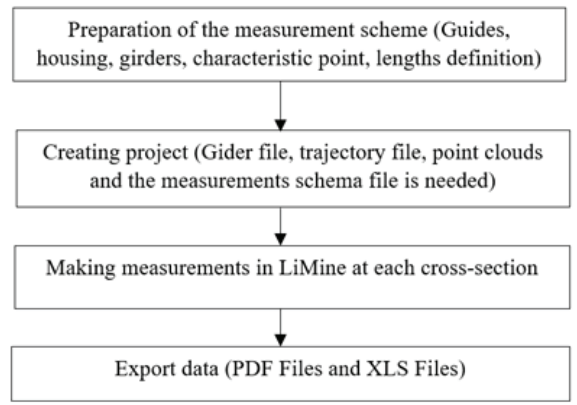

Fig. 15. Working process with the LiMine Program. Rys. 15. Proces pracy z programem LiMine

\subsection{Practice measurement by polish mobile laser scanner platform}

The measuring using the Mobile Mining Platform need to set the system on the head of the shaft cage, connect all necessary components, turn on the power and to start the dedicate application platform to control (Fig. 17). Depend on the type of measurement and its purpose, it may be necessary to stabilize geodetic points and measure with other classical methods. Purpose of this action - tie the laser scans performed to a given coordinate system (mine warp or national system). It also may be necessary to determine the moving line along the vertical direction for the platform's movement. Further works continue to perform the optimal orbital algorithms to accurately calculate the need for additional geodetic measurements. (Adamek, 2015).

Point cloud of the measurement process is a group of laser measurement results from 3 different scanners. Thanks to that, the registration of the object is completed.

Such a dense cloud of points allows you to conduct any analysis, as well as identify the deformation of shaft elements over time. From which, it can be monitored; identify vulner- able areas with a degree of wear of the shaft elements, pit, hoisting machines and other equipment and devise appropriate remedies.

MSS has been used in Poland in some cooperation projects with companies. Some of them are:

- Lubelski Węgiel Bogdanka S.A -cooperation project from 2010;

- KGHM Polska Miedż S.A - cooperation project from 2015;

- Jastrzębska Spółka Węglowa S.A.;

- Katowicki Holding Węglowy S.A.;

- Kompania Węglowa S.A.

\section{Conclusions}

TLS is an innovative technology, which can be used not only in the mining industry but also in many other applications. In recent years, TLS technology increasingly appreciated and used more and more in mining. It can be used to scan the surface and underground. TLS is also used to complement traditional measurements. In the mining industry, the invention of TLS and mobile TLS is considered a leap forward, a 


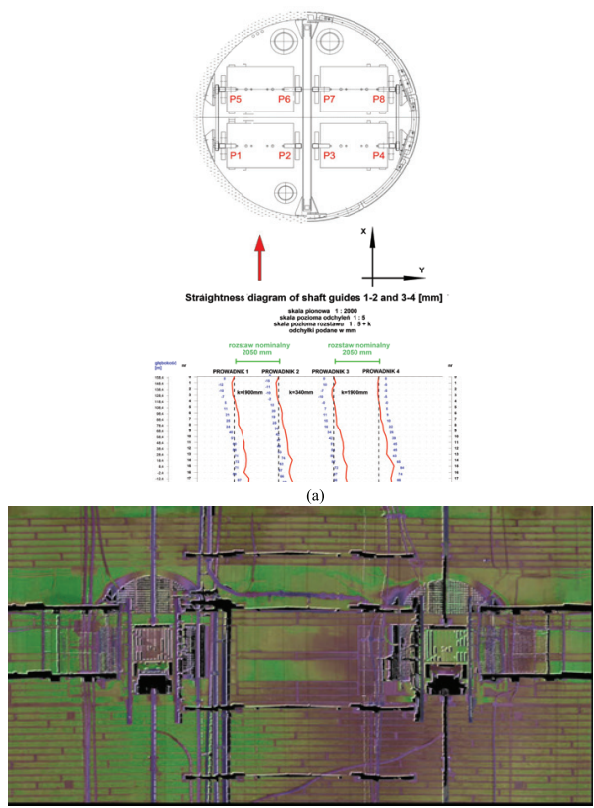

(b)

Fig. 16. Example of final report from shaft geometry analysis. (a) - straightness diagram of shaft guides, (b) - shaft deformation analysis (Lipecki Tomasz Adamek A, 2016) Fig. 16. Przykład raportu końcowego z analizy geometrii wału. (a) - prostoliniowość toru, (b) - analiza deformacji szybu

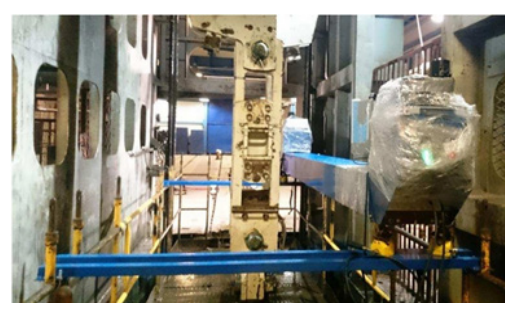

Fig. 17. Setup the Mobile Laser Scanning System in the shaft cage before measuring (SKALA 3D) Rys. 17. Ustaw mobilny laserowy system skanujący w klatce szybu przed pomiarem (SKALA 3D)

revolution to geodetic surveying in the field of shaft inventory. It is a solution that allows one to carry out shaft inventory measurements with high precision. This system with unique information technology, measurements in mines is more efficient and time-saving. This directly affects the economics of mining operations. Data obtained from measurement allows better management, supervision and ensuring better security.

In this paper, we have introduced the new mining measurement technology, which has been used very effectively in mines in Poland - The Polish Mobile Laser Scanning Platform. It gives accuracy at $1-3 \mathrm{~mm}$ in horizontal and 20-100 $\mathrm{mm}$ in the full length of vertical shafts (on $1000 \mathrm{~m}$ below ground). To date, it shows fantastic results, in which no other measuring methods can be reached. Moreover, this method increases the security of measurement and shortened time of their execution. The system needs only a few operators, and it is fit for every cage on a mining shaft.

We see that this technology can be applied in vertical shafts in Vietnam. The cost of buying this platform is high, but because of the working efficiency, it brings much greater than the classical measuring methods, it is necessary owned by all economic operators. It seems only a matter of time before it becomes normal as a working tool used by the operators. 


\section{Literatura - References}

1. Abmayr, T., Härtl, F., Reinköster, M., \& Fröhlich, C. (2005). Terrestrial laser scanning: Applications in cultural heritage conservation and civil engineering. Paper presented at the Proceedings of the ISPRS working group V4.

2. Adamek, A. (2015). Mobilna Platforma Górnicza (MPG)-nowatorskim rozwiązaniem w polskich kopalniach. Archiwum Fotogrametrii, Kartografii i Teledetekcji, 27.

3. Adamek, A., Bałchan, J., Krawiec, J., \& Lipecki, T. (2016). Innowacyjne rozwiązania pomiarowe do inwentaryzacji szybów górniczych. Wiadomości Górnicze, 67(2), 146--153.

4. Adamek A, L. T. (2016). Technologia mobilnego skanowania laserowego w badaniu prostoliniowości prowadników szybowych w odniesieniu do metody wideodetekcji plamki laserowej - [Mobile laser scanning technology in the research of straightness shaft guides in relation to the method of video detection laser spot]. Przegląd Geodezyjny, 4.

5. Adamek A, L. T. (2019). Kalibracja geometryczna Mobilnej Platformy Gorniczej jako element integracji sensorow pomiarowych.

6. Adamek A., B. J., Krawiec J., Lipecki T. (2014). Innovative measurement solutions for mining shaft inventory. Konferencja Szkoła Eksploatacji Podziemnej (School of Underground Mining SEP Conference).

7. Berenyi, A., Lovas, T., \& Barsi, A. (2010). Terrestrial laser scanning-civil engineering applications. International Archives of Photogrammetry, Remote Sensing and Spatial Information Sciences, 38(Part 5), 80-85.

8. Gallay, M., Kaňuk, J., Hochmuth, Z., Meneely, J. D., Hofierka, J., \& Sedlák, V. (2015). Large-scale and high-resolution 3-D cave mapping by terrestrial laser scanning: a case study of the Domica Cave, Slovakia. International Journal of Speleology, 44(3), 6.

9. Kumar, S., Tiwari, P. K., \& Chaudhury, S. (2006). An optical triangulation method for non-contact profile measurement. Paper presented at the 2006 IEEE International Conference on Industrial Technology.

10. Lerma, J. L., Navarro, S., Cabrelles, M., \& Villaverde, V. (2010). Terrestrial laser scanning and close range photogrammetry for 3D archaeological documentation: the Upper Palaeolithic Cave of Parpalló as a case study. Journal of Archaeological Science, 37(3), 499-507.

11. Lipecki, T. (2013). Kompleksowa ocena stanu geometrycznego obiektów i urządzeń szybowych z zastosowaniem skaningu laserowego: Wydawnictwa Akademii Górniczo-Hutniczej im. Stanisława Staszica.

12. Lipecki, T., Ligarska, H., \& Zawadzka, M. (2018). The influence of mining activities on the Church of St. Cross in Bytom-Miechowice. Reports on Geodesy and Geoinformatics, 105(1), 7-18.

13. Moorthy, I., Miller, J. R., Berni, J. A. J., Zarco-Tejada, P., Hu, B., \& Chen, J. (2011). Field characterization of olive (Olea europaea L.) tree crown architecture using terrestrial laser scanning data. Agricultural and Forest Meteorology, 151(2), 204-214.

14. Nghĩa, N. V., \& Dũng, V. N. (2016). Research on the applicability of 3D laser scanner in construction management underground mining.

15. Quintero, M., Genechten, B., Bruyne, M., Ronald, P., Hankar, M., \& Barnes, S. (2008). Theory and practice on terrestrial laser scanning. Learning Tools for Advanced Three-dimensional Surveying in Risk Awareness Project (3DRiskMapping).

16. Romsek, B. R. (2008). Terrestrial laser scanning: Comparison of time-of-flight and phase based measuring systems.

17. Tomasz Lipecki, A. A. (2015). Opracowanie nowej metodyki monitorowania stanu techniczego szybow gorniczych z wykorzystaniem technologii mobilnego skanowania laserowego.

18. Vosselman, G., \& Maas, H.-G. (2010). Airborne and terrestrial laser scanning: CRC press. 
Technologia Laserowego Skanowania Naziemnego Zastosowania w Szybie Pionowym w Polsce Skanery laserowe sa coraz częściej używane jako urzadzenia geodezyjne do różnych zastosowań. Wraz z rozwojem systemów o wysokiej precyzji, skanery laserowe moga pracować $w$ większości rzeczywistych środowisk w wielu różnych warunkach. $W$ dziedzinie geodezji górniczej otwieraja się nowe metody gromadzenia danych. Górnictwo wymaga precyzyjnych danych, aby móc posiadać dokumentacje powykonawcza obiektu. Obecnie kopalnie sa coraz bardziej pogtębione. Dla bezpiecznej eksploatacji podziemnej kopalni szczególna uwage przywiazuje się do transportu pionowego oraz zespołu wspierajacych urzadzeń, zamontowanych w szybach górniczych. Wszystkie komponenty musza spełniać rygorystyczne kryteria prawidłowego działania. Klasyczne pomiary geodezyjne i badania mechaniczne sa dlugotrwałe i nie zawsze dostarczaja pelnego zakresu potrzebnych informacji o stanie obiektu. W artykule opisano metodę naziemnego skanowania laserowego oraz systemowe mobilne naziemne skanowanie laserowe, które zostało zastosowane $w$ wielu pionowych szybach $w$ polskich kopalniach do wyznaczania odksztatceń geometrycznych pionowych elementów szybów. System ten daje wysoka precyzje 1-3 mm w każdego przekroju poziomym. Czas przetwarzania jest bardzo szybki, a do wdrożenia całego systemu potrzeba tylko kilku pracowników.

Słowa kluczowe: skanowanie laserowe, naziemne skanowanie laserowe, mobilne naziemne skanowanie laserowe, polski system geodezji górniczej, TLS, MTLS, MSS 